\title{
DAYA SAING EKSPOR LADA INDONESIA DI PASAR AMERIKA DAN EROPA
}

\author{
Putroe Balqis'), dan Rahmat Yanuar'2) \\ 1,2)Departemen Agribisnis, Fakultas Ekonomi dan Manajemen, Institut Pertanian Bogor \\ Jl. Kamper Wing 4 Level 5 Kampus IPB Dramaga Bogor, Indonesia \\ e-mail: 2)r_yanuar@apps.ipb.ac.id
}

(Diterima 25 Juli 2020 / Revisi 12 Agustus 2021 / Disetujui 10 September 2021)

\begin{abstract}
As a major producing country, Indonesia is one of the world's largest pepper exporters where America and some European Union countries have become the destinations of its exports. The purposes of this study are to analyze the performance of Indonesian pepper and the development of its exports and to analyze the competitiveness of Indonesian pepper exports in American and European markets, especially in the period 2004-2018. This research used descriptive analysis from the trade data period 2004-2018, to analyze the performance of Indonesian pepper. From the same data set, this study used competitiveness analysis with the Revealed Comparative Advantage (RCA) method, Export Product Dynamics (EPD), and Trade Specialization Index (ISP). The results showed that the area of cropland and production of Indonesian pepper had decreased, the development of Indonesian pepper exports was also quite volatile. Based on the calculation of RCA, Indonesia has competitiveness or comparative advantage for exports to Germany, the Netherlands, France, Italy and Belgium. The EPD value showed Indonesia was in a Retreat position in the Netherlands, Germany and Belgium. While Indonesia is in the position of Rising Star in Italy, Falling Star in France, and Lost Opportunity in America. Finally, The ISP value showed that Indonesia has strong competitiveness as an exporter of whole pepper.
\end{abstract}

Keywords: competitiveness, EPD, ISP, pepper, RCA

\begin{abstract}
ABSTRAK
Sebagai negara produsen utama, Indonesia menjadi salah satu negara eksportir lada terbesar di dunia di mana negara-negara yang menjadi tujuan ekspor diantaranya adalah Amerika dan beberapa negara Uni Eropa. Penelitian ini bertujuan untuk menganalisis kinerja lada Indonesia dan perkembangan ekspornya. Selain itu studi ini juga bertujuan untuk menganalisis daya saing ekspor lada Indonesia di pasar Amerika dan Eropa khususnya pada periode tahun 2004-2018. Menggunakan data perkembangan ekspor lada Indonesia periode 2004-2018, dilakukan analisis deskriptif untuk melihat keragaan lada Indonesia. Menggunakan data set yang sama, dilakukan analisis daya saing dengan menggunakan analisis Revelead Comparative Advantage (RCA), Export Product Dynamics (EPD), dan Indeks Spesialisasi Perdagangan (ISP). Hasil studi ini memperlihatkan keragaan lada Indonesia berdasarkan luas lahan dan produksi yang memiliki kecenderungan mengalami penurunan. Sedangkan dari sisi ekspor terlihat adanya perkembangan yang fluktuatif. Secara daya saing, berdasarkan nilai RCA, terlihat lada Indonesia memiliki daya saing untuk tujuan ekspor ke Jerman, Belanda, Prancis, Italia, dan Belgia. Sedangkan berdasarkan nilai EPD, memperlihatkan posisi daya saing lada Indonesia di negara Belanda, Jerman dan Belgia berada pada posisi Retreat. Di sisi lain, lada Indonesia memiliki posisi daya saing Rising Star di Italia, Falling Star di Prancis, dan Lost Opportunity di Amerika. Terakhir, berdasarkan nilai ISP, dapat ditunjukan bahwa Indonesia memiliki daya saing yang kuat sebagai eksportir lada utuh.
\end{abstract}

Kata kunci: daya saing, EPD, ISP, lada, RCA

\section{PENDAHULUAN}

Lada Indonesia memiliki potensi yang besar. Hal ini ditunjukkan dengan tingginya kuantitas ekspor lada Indonesia di negara tujuan ekspor. Berdasarkan data tahun 2019, posisi Indonesia sebagai negara eksportir berada pada urutan ketiga setelah Vietnam dan Brazil. Selain itu juga ditunjukkan dari nilai ekspornya yang mencapai US\$14.83 miliar (bulan Mei 2019) atau 
naik sebesar $13.05 \%$ dibanding ekspor di bulan sebelumnya (April 2019). Komoditi lada ini juga menyumbang cukup besar terhadap sub sektor perkebunan, di mana sub sektor ini memiliki potensi terbesar bagi sektor pertanian yang saat ini berkontribusi $12 \%$ dari total PDB. Potensi sub sektor perkebunan, termasuk komoditas lada ini juga terlihat dari penguasaan pangsa pasar ekspor yang cukup besar yang menunjukkan kemampuan daya saing di pasar internasional (BPS 2019).

Komoditas lada termasuk ke dalam sepuluh komoditas andalan pertanian Indonesia, di mana sebagian besar lada Indonesia diekspor dalam bentuk lada utuh. Di pasar dunia, Lada hitam Indonesia dikenal dengan nama "Lampung Black Pepper" dan "Munthok White Pepper" untuk lada putih. Produk lada dipasarkan secara global dengan Harmonized System Code (HS Code), untuk produk lada utuh (HS 090411 atau pepper of the genus piper, neither crushed nor ground) dan lada bubuk (HS 090412 atau pepper of the genus piper, crushed or ground). Menurut data Ditjen Perkebunan periode 2015-2019 tren jumlah dan nilai ekspor lada Indonesia terlihat menurun. Namun untuk tahun 2018, ekspor lada Indonesia mencapai sebesar 47,6 ribu ton, dengan nilai ekspor US\$ 152,46 juta di mana terlihat jumlah dan nilai ekspor ini mengalami peningkatan dibanding tahun 2017. Beberapa negara tujuan ekspor lada Indonesia adalah Vietnam, Amerika, Singapura, India, Jerman, dan Belanda (Tabel 1).

Tabel 1. Ekspor Lada menurut Negara Tujuan Utama, Tahun 2017

\begin{tabular}{lrrr}
\hline \multicolumn{1}{c}{ Negara } & $\begin{array}{c}\text { Berat } \\
\text { Bersih: } \\
\text { Ton }\end{array}$ & $\begin{array}{c}\text { Nilai } \\
\text { FOB: } \\
\text { 000 US\$ }\end{array}$ & $\begin{array}{c}\text { Harga: } \\
\text { 000 US\$ } \\
\text { /Ton }\end{array}$ \\
\hline Vietnam & 11,173 & 49,442 & 4,425 \\
Singapura & 2,191 & 15,655 & 7,145 \\
Amerika & & & \\
Serikat & 2,607 & 20,242 & 7,765 \\
Belanda & 940,1 & 7,630 & 8,117 \\
Jepang & 461,9 & 3,732 & 8,081 \\
Jerman & 1,654 & 11,904 & 7,197 \\
Taiwan & 740,4 & 5,274 & 7,124 \\
Malaysia & 569,5 & 4,754 & 8,349 \\
Perancis & 226 & 2,115 & 9,362 \\
India & 1,031 & 4,328 & 4,195 \\
Lainnya & 1,151 & 8,396 & 7,295 \\
\hline Jumlah & $\mathbf{2 2 , 7 4 6}$ & $\mathbf{1 3 3 , 4 7 7}$ & \\
\hline Sumber: Badan Pusat Statistik 2019 & &
\end{tabular}

Harga lada di pasar dunia cenderung memiliki tren meningkat, selain harga yang tinggi permintaan lada dunia juga terus meningkat seiring dengan penambahan jumlah penduduk, ini membuktikan bahwa komoditas lada layak dikembangkan. Meskipun ekspor lada Indonesia ke Amerika, Jerman, Prancis, dan Belanda jumlahnya kurang dari total ekspor ke Vietnam, namun penawaran harga yang ditetapkan oleh Amerika, Jerman, Prancis, dan Belanda jauh di atas harga yang ditawarkan oleh Vietnam, dengan harga masing-masing sebesar US\$ 7,765 ribu/ton, US\$ 7,197 ribu/ton, US\$ 9,362 ribu/ton, dan US\$ 8,117 ribu/ton, sedangkan Vietnam memberikan tawaran harga sebesar US\$ 4,425 ribu/ton lada pada tahun 2017 (Tabel 1). Menurut data ITC (2019) sebesar 11\% lada Indonesia diekspor ke Amerika, 5,9\% ke Jerman, dan 4,8\% di ekspor ke Belanda, meski nilai ekspor ke Amerika dan beberapa negara Uni Eropa masih berada di bawah nilai ekspor ke Vietnam.

Salah satu penyebab rendahnya nilai ekspor lada Indonesia ke beberapa negara Eropa dan Amerika adalah masih rendahnya standar mutu produk. Salah satu penyebab rendahnya mutu lada adalah akibat kontaminasi mikroorganisme dikarenakan sistem produksi petani Indonesia yang masih tradisional. Karena itu perhatian terhadap standar mutu lada menjadi hal penting ketika akan masuk dalam pasar Internasional karena akan semakin mempengaruhi harga jual dan permintaan pasar. Hal ini juga terkait dengan permintaan lada Indonesia relatif sensitif terhadap perubahan harga (Mahdi dan Suprehatin, 2021)

Selain itu, adanya isu bahwa Kementerian Pertanian melalui Badan Karantina Pertanian akan mengalihkan pasar lada ke Amerika, dan Eropa, agar petani mendapatkan harga jual yang lebih tinggi. Pengalihan pasar ekspor dari pasar Vietnam dan Singapura dikarenakan kedua negara ini melakukan re-ekspor lada Indonesia dengan melakukan pengolahan kembali sebelum kemudian diekspor ke negara tujuan utama yaitu Eropa dan Amerika. Kementrian Pertanian berupaya agar semua produk berpotensi Indonesia dapat diekspor langsung ke negara tujuan tanpa harus transit dahulu di negara lain, 
untuk mendapatkan nilai tambah langsung dari perdagangan yang dilakukan.

Berdasarkan data pada Gambar 1, sebagian besar produk lada Indonesia diekspor ke Amerika dan beberapa negara Uni Eropa. Hal ini menunjukkan pasar lada di Amerika dan Uni Eropa cukup potensial yang menunjukkan tingkat konsumsinya yang tinggi. Menurut data ITC (2019), Amerika adalah negara importir lada terbesar dunia, dengan nilai impor pada tahun 2018 mencapai US\$ 2.612,379 ribu, namun Indonesia hanya mampu mengekspor lada ke Amerika sebesar US\$17,872 ribu pada tahun yang sama. Banyaknya pesaing menjadi ancaman bagi Indonesia untuk masuk ke pasar Eropa dan Amerika.

Upaya peningkatan daya saing dari produk yang akan diekspor merupakan salah satu upaya untuk meningkatkan ekspor. Secara definisi, daya saing adalah kekuatan suatu komoditas untuk dapat masuk dan bertahan di pasar tersebut, termasuk di pasar luar negeri (Kemendag 2015). Daya saing harus dimiliki oleh negara yang ingin tetap eksis dalam perdagangan bebas ini.

Oleh karena itu, peningkatan daya saing penting untuk dilakukan mengingat bahwa Indonesia bukan satu-satunya negara pengekspor lada dunia, pesaing utama Indonesia dalam pasar lada dunia adalah Vietnam, Brazil, India dan Malaysia. Indonesia memiliki pangsa pasar produksi lada yang cukup besar namun hanya memenuhi kurang dari 50\% pangsa pasar dunia (ITC 2019). Secara eksplisit, penelitian ini ingin mengetahui bagaimana perkembangan ekspor dan daya saing lada Indonesia di pasar Amerika dan Eropa?

Beberapa penelitian terkait daya saing lada sudah dilakukan beberapa peneliti di Indonesia. Seperti studi yang dilakukan oleh Permatasari (2015); Suminto dan Hadiyanto (2017); Ariesha (2017) dan Athiyah (2018). Namun negara tujuan ekspor dalam penelitian sebelumnya berbeda dengan yang dilakukan dalam penelitian ini yaitu Amerika, Belanda, Jerman, Italia, Prancis, dan Belgia. Sedangkan dalam hal metode, Permatasari (2015) melakukan penelitian untuk mengukur daya saing berupa keunggulan komparatif dengan menggunakan analisis Revealed Comparative Advantage (RCA). Namun dalam penelitiannya ini tidak dilakukan analisis daya saing kompetitif. Namun, dalam penelitian tersebut dilakukan analisis posisi daya saing menggunakan Indeks Spesialisasi Perdagangan (ISP). Studi lainnya yang dilakukan oleh Ariesha (2017), selain melihat daya saing berdasarkan keunggulan komparatif, juga melakukan analisis daya saing kompetitif dengan menggunakan analisis Export Product Dynamic (EPD). Studi yang dilakukan saat ini menggabungkan metode analisis daya saing yang dilakukan dalam studi Permatasari (2015) dan

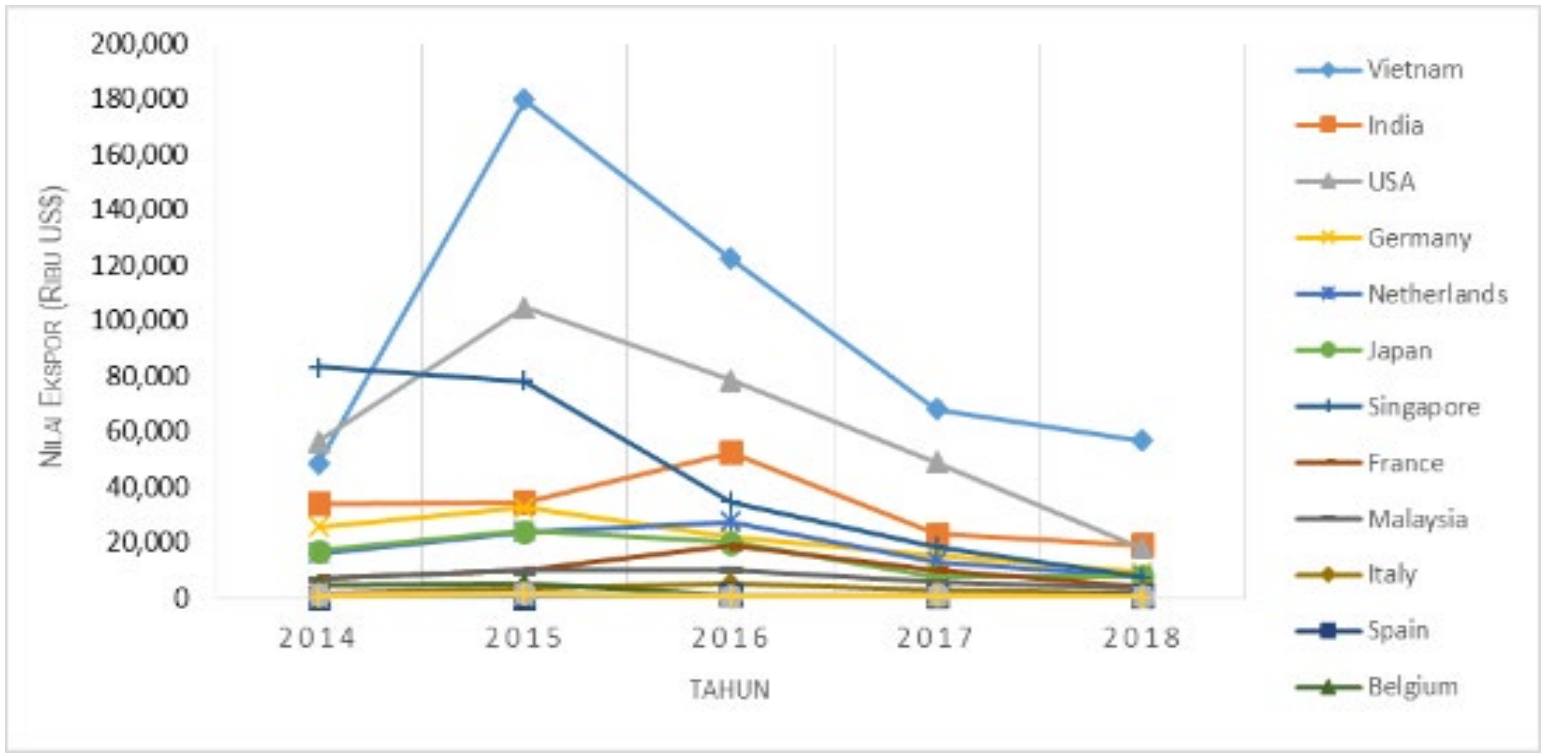

Gambar 1. Perkembangan Ekspor Lada Indonesia Berdasarkan Negara Tujuan, Tahun 2014-2018. 
Ariesha (2017) untuk menjawab pertanyaan penelitian yang sudah diformulasi pada beberapa paragraf sebelumnya. Sehingga tujuan penelitian dapat dirumuskan sebagai berikut:

1. Menganalisis kinerja lada Indonesia dan perkembangan ekspor lada Indonesia di pasar Amerika dan Eropa.

2. Menganalisis daya saing ekspor lada Indonesia di pasar Amerika dan Eropa.

\section{METODE}

Penelitian ini menggunakan data skunder untuk menjawab tujuan penelitian yang sudah dirumuskan. Data yang digunakan adalah data sekunder data potensi produksi dan perdagangan lada baik nasional maupun data internasional. Data yang digunakan berupa data deret waktu (time series) yang menunjukkan perkembangan luas lahan, produksi dan produktivitas lada nasional. Selain itu juga data deret waktu dari ekspor lada Indonesia, ekspor lada dunia, impor lada dunia, dan impor lada negara tujuan. Periode data yang digunakan yaitu periode tahun 2004 2018, dengan negara tujuan ekspor yaitu Amerika, Belanda, Jerman Belgia, Prancis, dan Italia. Jenis lada pada penelitian ini adalah lada dengan kode Harmonized System (HS) lada 090411 (Pepper of the genus Piper, neither crushed nor ground). Data bersumber dari Badan Pusat Statistik (BPS), Kementrian Pertanian, Kementrian Perdagangan, Dirjen Perkebunan, International Trade Centre (ITC).

\section{Metode Analisis dan Pengolahan Data}

Tujuan pertama dari penelitian ini dijawab menggunakan analisis deskriptif dan tabulasi sederhana untuk melihat kinerja lada Indonesia dan perkembangan ekspor di negara tujuan yaitu Amerika dan beberapa negara Eropa. Sedangkan tujuan kedua dari penelitian ini dijawab dengan melakukan analisis daya saing dari Amerika dan Eropa menggunakan metode RCA, EPD dan IPS. Ketiga metode analisis ini dijelaskan secara lebih detail berikut ini.

\section{Revealed Comparative Advantage (RCA)}

Metode analisis RCA bertujuan untuk menganalisis posisi keunggulan komparatif suatu produk atau komoditas, dalam hal ini lada Indo- nesia di antara negara-negara penghasil lada lainnya di pasar internasional. Secara umum perhitungan RCA dapat dirumuskan sebagai berikut:

$$
R C A=(X i j /(X t)) /(W i j / W t)
$$

Di mana:

RCA = tingkat daya saing lada Indonesia di pasar ekspor Amerika dan Eropa

$\mathrm{Xij}=$ nilai ekspor komoditi $i$ (lada Indonesia) $\mathrm{di}$ pasar ekspor $j$ (Amerika dan Eropa)

$\mathrm{Xt} \quad=$ nilai total ekspor Indonesia

Wij = nilai ekspor komoditi $i$ (lada) dunia di pasar ekspor $j$ (Amerika dan Eropa)

$\mathrm{Wt}=$ nilai total ekspor dunia

Studi ini juga menggunakan nilai Indeks RCA yang merupakan rasio dari nilai RCA tahun tertentu dengan nilai RCA tahun sebelumnya. Secara matematis Indeks RCA ini dapat dituliskan sebagai berikut :

$$
\text { Indeks RCA }=\frac{\mathrm{RCAj}}{\mathrm{RCAj}-1}
$$

Di mana :

RCA $j$ : nilai RCA tahun ke $j$

RCAj-1 : nilai RCA tahun ke $j-1$

Interpretasi dari nilai dan Indeks RCA memiliki dua kemungkinan yaitu :

1. Apabila nilai RCA > 1, dapat dikatakan keunggulan komparatif negara tersebut berada di atas rata-rata dunia dan komoditi ekspor negara tersebut memiliki daya saing yang kuat.

2. Apabila nilai RCA $<1$, dapat dikatakan keunggulan komparatif negara tersebut berada di bawah rata-rata dunia dan komoditi ekspor negara tersebut memiliki daya saing yang lemah.

\section{Eksport Product Dynamic (EPD)}

Nilai EPD digunakan untuk mengetahui dan menganalisis keunggulan kompetitif negara pengekspor terhadap suatu produk atau komoditi yang diekspor. Nilai EPD kemudian dipetakan dalam matriks posisi daya saing seperti yang ditunjukkan pada Gambar 2. 


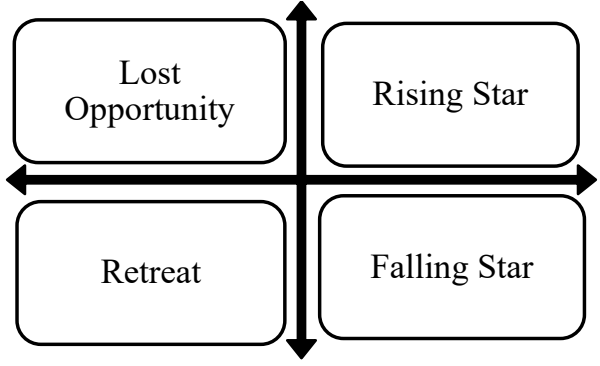

\section{Gambar 2. Matrik Posisi Daya Saing dengan Metode EPD Sumber : Nabi \& Luthria (2002)}

Matriks tersebut menggambarkan posisi daya saing berdasarkan pangsa ekspor suatu negara $i \mathrm{di}$ pasar tujuan (sumbu horizontal) dan pangsa produk $j$ di pasar tujuan (sumbu vertikal).

Matriks EPD ini terdiri dari empat kuadran yaitu Rising Star, Lost Opportunity, Falling Star, dan Retreat. Posisi Rising Star dianggap sebagai posisi pasar tertinggi, di mana posisi ini juga dianggap sebagai posisi pasar yang paling ideal. Sedangkan posisi Lost Opportunity menunjukkan posisi daya saing atau kondisi pasar yang tidak diharapkan. Hal ini karena pada posisi ini terjadi penurunan pangsa pasar sehinga berakibat hilangnya kesempatan suatu negara untuk menguasai pangsa ekspor produk dan barang di pasar internasional. Posisi pasar atau posisi daya saing lainnya yang tidak diharapkan adalah Falling Star, jika dibandingkan dengan posisi Lost Opportunity, posisi ini masih lebih baik. Peningkatan pangsa pasar masih terjadi pada posisi ini, namun di pasar global peningkatannya tidak pada produk atau barang yang kontinu (dinamis). Posisi daya saing Retreat terjadi pada kondisi pangsa yang sudah tidak menginginkan produk atau barang dari suatu negara tersebut.

Dalam penelitian ini, model pangsa pasar ekspor suatu negara dan pangsa pasar suatu komoditi dapat ditunjukkan sebagai berikut.

Sumbu X: Pertumbuhan pangsa pasar ekspor atau disebut kekuatan bisnis

$$
\frac{\sum_{t=1}^{t}\left(\left(\frac{X i j}{W i j}\right) t \times 100 \%-\left(\frac{X i j}{W i j}\right) t-1 \times 100 \%\right)}{T}
$$

Sumbu Y: Pertumbuhan pangsa pasar produk

$$
\frac{\sum_{t=1}^{t}\left(\left(\frac{X t}{W t}\right) t \times 100 \%-\left(\frac{X t}{W t}\right) t-1 \times 100 \%\right)}{T}
$$

Di mana:

Xij = Nilai ekspor komoditi $i$ (lada Indonesia) ke negara $j$ (Amerika dan Eropa)

$\mathrm{Xt}=$ Total nilai ekspor Indonesia ke negara $j$ (Amerika dan Eropa)

Wij $=$ Nilai ekspor komoditi $i$ (lada) dunia ke negara $j$ (Amerika dan Eropa)

$\mathrm{Wt}=$ Total nilai ekspor dunia ke negara $j$ (Amerika dan Eropa)

$\mathrm{T}=$ Jumlah tahun

\section{Indeks Spesialisasi Perdagangan (ISP)}

Indeks Spesialisasi Perdagangan (ISP) merupakan suatu nilai untuk menganalisis daya saing dengan melihat posisi atau tahapan perkembangan suatu produk. Nilai indeks ini untuk melihat kecenderungan suatu jenis produk berdasarkan nilai ekspornya menjadikan negara tersebut (misal Indonesia) sebagai negara eksportir atau menjadi negara importir (Kemendag 2019). Indeks ini, secara matematika dapat dirumuskan seperti berikut:

$$
I S P i j=(\mathrm{Xij}-\mathrm{Mij}) /(X i j+M i j)
$$

Di mana:

ISPij = Indeks Spesialisasi Perdagangan produk atau komoditi lada negara $i$ di tahun $j$

$\mathrm{Xij}=$ Nilai ekspor produk atau komoditi lada negara $i$ di tahun $j$

Mij = Nilai impor produk atau komoditi lada negara $i$ di tahun $j$

Nilai indeks yang diperoleh dari perhitungan akan berkisar antara -1 sampai dengan +1. Jika nilai indeks positif (antara $0-1$ ) dapat dikatakan bahwa komoditi yang dianalisis memiliki daya saing yang kuat atau negara tersebut berpotensi sebagai pengekspor dari yang dianalisis. Hal ini dicirikan dengan penawaran domestik lebih besar daripada permintaan domestik. Namun apabila nilai indeks nya di bawah 0 hingga -1 , maka menunjukkan daya saingnya komoditi lemah atau negara cenderung importir. Dalam hal ini, penawaran domestik lebih kecil dari permintaan domestik. 


\section{HASIL DAN PEMBAHASAN}

\section{PERKEMBANGAN LUAS AREAL LADA INDONESIA TAHUN 2004-2018}

Menurut data dari Badan Pusat Statistik, luas areal lada Indonesia selama periode tahun 2004-2018 mengalami fluktuasi yang cenderung menurun. Pada tahun 2004 total luas lahan lada nasional mencapai 201 ribu ha, namun pada tahun 2012 luas lahan lada hanya sebesar 117 ha terjadi penurunan hingga 59 ha dari tahun 2011 (Gambar 3). Menurut Pusat Perpustakaan Dan Penyebaran Teknologi Pertanian (2018), penurunan luas lahan lada nasional ini disebabkan oleh adanya kekeringan, serangan hama dan penyakit, konversi lahan tanaman lada ke komoditi perkebunan lainnya, dan adanya pembukaan lahan tambang.

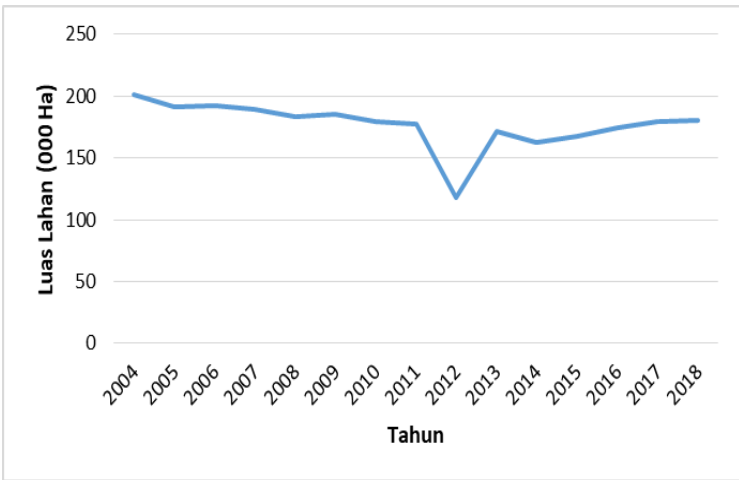

Gambar 3. Perkembangan Luas Areal Perkebunan Lada Nasional Tahun 2004-2018 Sumber: BPS (data diolah) 2019

Hingga tahun 2014 perkebunan lada tersebar di berbagai daerah Indonesia, beberapa provinsi dengan luas areal lada terbesar di Indonesia (Gambar 4) yaitu, pada peringkat pertama ditempati oleh provinsi Lampung dengan luas lahan mencapai 48.223 ha (34\%), peringkat kedua ditempati oleh Kepulauan Bangka Belitung dengan luas lahan mencapai 44.992 ha (22\%), diikuti oleh Sulawesi Tenggara dengan luas lahan mencapai 13.894 ha $(7 \%)$, provinsi Sulawesi Selatan mencapai 13.037 ha (7\%), dan Kalimantan Timur dengan luas areal lada sebesar 9.482 ha (7\%).

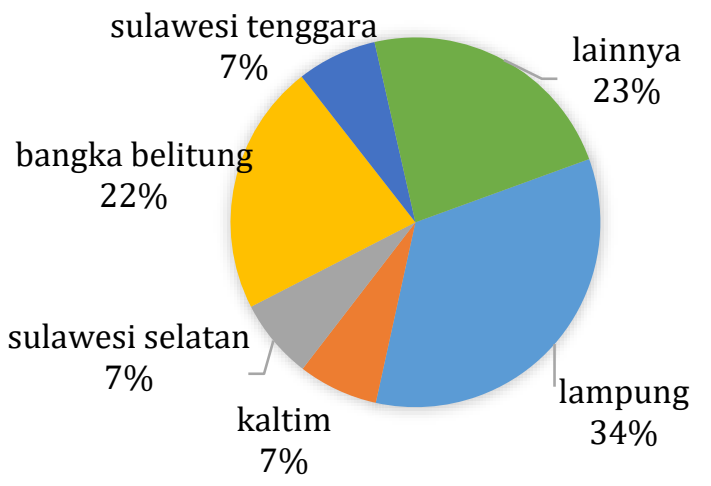

\section{Gambar 4. Provinsi dengan Rata-rata Luas Areal Terbesar di Indonesia}

Menurut data dari Direktorat Jendral Perkebunan (2016) mayoritas perkebunan lada Indonesia dikelola oleh perkebunan rakyat yang menguasai 99,87\% kebun lada Indonesia, sementara perkebunan besar swasta hanya menguasai $0,13 \%$ dari total perkebunan lada Indonesia. Sehingga perkembangan naik turunya luas lahan lada nasional dipengaruhi oleh perkembangan luasan lada rakyat.

\section{PERKEMBANGAN PRODUKSI DAN PRODUKTIVITAS LADA INDONESIA}

Menggunakan data periode 2004-2018 dapat dianalisis perkembangan produksi lada Indonesia. Tingkat produksi tertinggi lada pada periode tersebut dicapai pada tahun 2013 (Gambar 5) dengan angka produksi 91 ribu ton. Sedangkan produksi terendah terjadi pada tahun 2007 yang hanya mencapai 74 ribu ton. Produksi lada Indonesia masih menunjukkan adanya tren peningkatan, dengan tingkat produksi tahun 2018 naik menjadi 85 ribu ton di bandingkan tahun 2017.

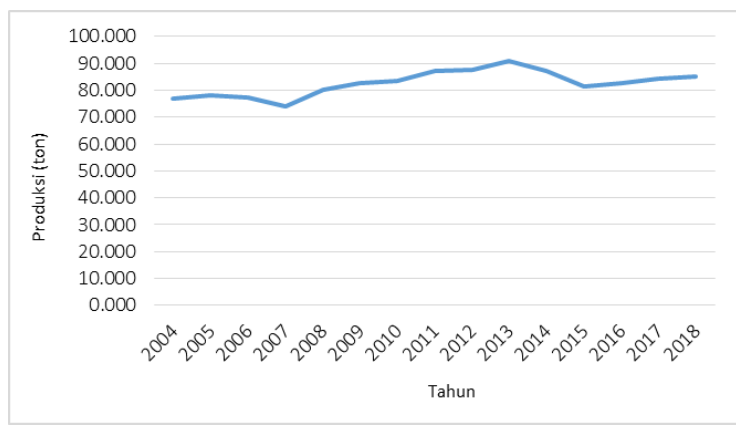

Gambar 5. Perkembangan Produksi Lada Indonesia Tahun 2004-2018

Sumber: BPS (data diolah) 2019 
Ada lima provinsi sentra lada di Indonesia. Hal ini mengacu pada data rata-rata produksi lada Indonesia tahun 2004-2018, dengan pangsa produksi kumulatif dari kelima provinsi tersebut mencapai $78 \%$ dari total produksi nasional. Kelima provinsi tersebut adalah Kepulauan Bangka Belitung, Lampung, Kalimantan Timur, Sumatera Selatan, dan Sulawesi Selatan (Gambar 6).

Kepulauan Bangka Belitung merupakan salah satu provinsi sentra lada Indonesia. Jika dilihat dari segi luas lahan Kepulauan Bangka Belitung menempati urutan kedua dengan luas lahan kurang dari provinsi Lampung, namun dari segi produksi provinsi berada di urutan pertama dengan pangsa produksi 28\% per tahun di mana rata-rata produksinya sebesar 20.621 ton per tahunnya. Kemudian peringkat kedua ditempati oleh Lampung yang berkontribusi 25\% dengan rata-rata produksi sebesar 17.909 ton per tahun, diikuti oleh Kalimantan Timur, Sumatera Selatan, dan Sulawesi Selatan masing-masing dengan ratarata pangsa produksi lada per tahunnya sebesar 7.016 ton $(10 \%), 6.351$ ton (9\%), dan 4.674 ton (6\%) (Gambar 6), sedangkan pangsa produksi provinsi lainnya kurang dari $5 \%$ per tahun.

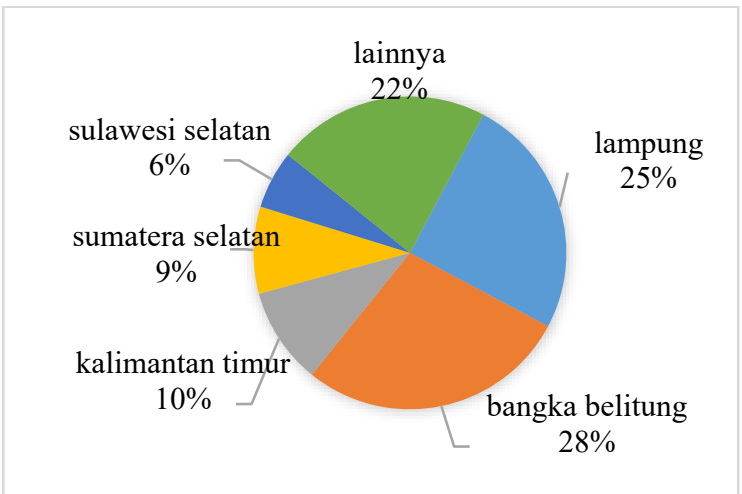

\section{Gambar 6. Provinsi yang Menjadi Sentra Produksi Lada Indonesia}

\section{PERKEMBANGAN EKSPOR DAN IMPOR LADA INDONESIA}

Lada adalah komoditi rempah-rempah unggulan Indonesia yang sejak dulu sudah menjadi komoditi yang diperdagangkan di pasar internasional. Perkembangan volume ekspor lada Indonesia cukup berfluktuatif (Gambar 7), seperti terlihat pada periode 2004-2010 di mana volume ekspor lada Indonesia cenderung naik mencapai 62.213 ton, namun kemudian pada tahun 2011 volume ekspor lada Indonesia menurun drastis hingga 35.568 ton. Pada tahun berikutnya (2012) menjadi 61.649 ton, setelah itu menurun kembali pada tahun 2014 menjadi 33.348 ton. Hingga tahun 2018 volume ekspor lada utuh Indonesia hanya mencapai 46.503 ton. Selain menjadi negara pengekspor lada, Indonesia juga mengimpor lada dari beberapa negara lainnya, namun secara umum volume impor komoditi ini masih relatif rendah dengan rata-rata per tahunnya hanya berkisar antara 2.169 ton (Gambar 7).

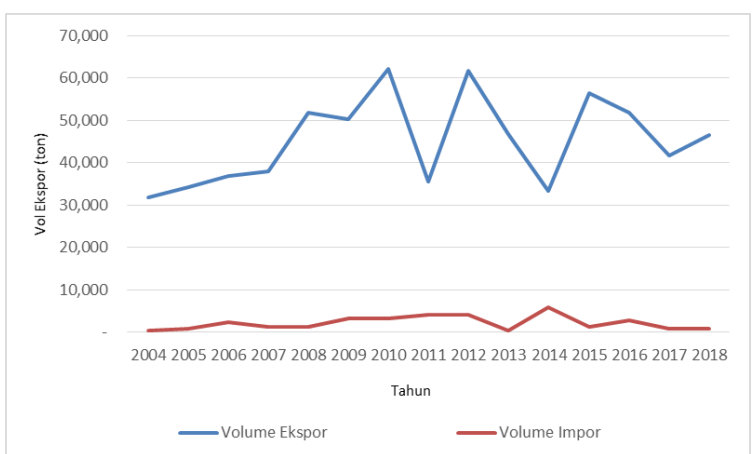

Gambar 7. Perkembangan Volume Ekspor dan Impor Lada Indonesia Tahun 2004-2018

Perkembangan nilai ekspor lada Indonesia pada 2004-2018 juga cukup berfluktuatif tetapi memiliki trend yang meningkat (Gambar 8), nilai ekspor tertinggi terjadi di tahun 2015 di mana mencapai US\$ 531.642. Peningkatan nilai ekspor ini terjadi hingga tahun 2016, nilai ekspor lada Indonesia menurun drastis pada tahun 2017 dan masih menurun pada tahun berikutnya di mana nilai ekspor lada utuh hanya mencapai US\$ 147,389. Negara eksportir lada terbesar lainnya adalah Vietnam, Brazil, dan India.

Sebagai negara eksportir, Indonesia menempati peringkat kedua di dunia dengan ratarata nilai ekspor pada periode tahun 2004-2018 yaitu US\$232.266. Beberapa negara yang menjadi tujuan ekspor lada Indonesia adalah Vietnam, Amerika, Belgia, Italia, Belanda, Prancis dan Jerman. Dinamika ekspor ke beberapa negara tujuan ekspor ini, terutama terkait daya saing, akan dibahas secara khusus pada paragraf berikutnya. 


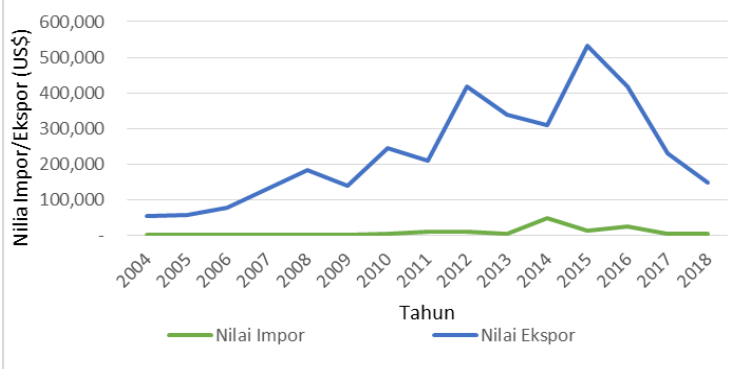

Gambar 8. Perkembangan Nilai Ekspor dan Impor Lada Indonesia Tahun 2004-2018

\section{DAYA SAING EKSPOR LADA INDONESIA}

\section{Daya Saing Komparatif}

Keunggulan komparatif dapat dianalisis dengan metode Revealed Comparative Advantage (RCA). Suatu negara dikatakan memiliki daya saing atau keunggulan komparatif yang semakin kuat jika nilai RCA semakin besar. Dasaya saing komparatif dalam penelitian ini menggunakan pengukuran RCA dinamis yang memasukkan unsur waktu agar dapat melihat pangsa pasar relatif dari waktu ke waktu. Untuk lebih jelas hasil analisis Indeks RCA lada utuh Indonesia ke negara tujuan ekspor dapat dilihat pada Gambar 9, berikut ini.

Nilai Indeks RCA

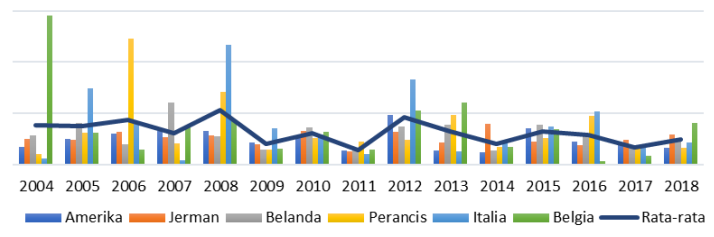

Gambar 9. Hasil Analisis Indeks RCA Lada Utuh Indonesia ke Negara Tujuan Ekspor Tahun 2004-2018

Dari Gambar 9 dapat dilihat bahwa secara dinamis ada pergeseran daya saing lada Indonesia di Amerika di mana tren daya saingnya terlihat dari tahun ke tahun ada penurunan. Hal ini agak berbeda dengan daya saing lada Indonesia di Eropa yang terlihat beberapa negara seperti Italia dan Perancis memiliki tren peningkatan daya saing. Beberapa isu yang menyebabkan adanya dinamika daya saing di negara tujuan ini akan dibahas pada beberapa paragraf selanjutnya.
Pada periode 2004-2018, lada utuh Indonesia memiliki nilai RCA rata-rata lebih dari satu di pasar Jerman $(1,04)$, Belanda $(1,17)$, Prancis $(1,37)$, Italia $(1,50)$, dan Belgia $(1,47)$, yang mengidentifikasikan lada utuh Indonesia memiliki daya saing atau keunggulan komparatif di pasar Jerman, Belanda, Prancis, Italia, dan Belgia (Gambar 10). Hal ini menunjukkan bahwa Indonesia mampu untuk mengelola pasar Eropa dengan baik terutama dalam menghadapi persaingan dengan beberapa negara produsen Asia seperti Vietnam dan Malaysia.

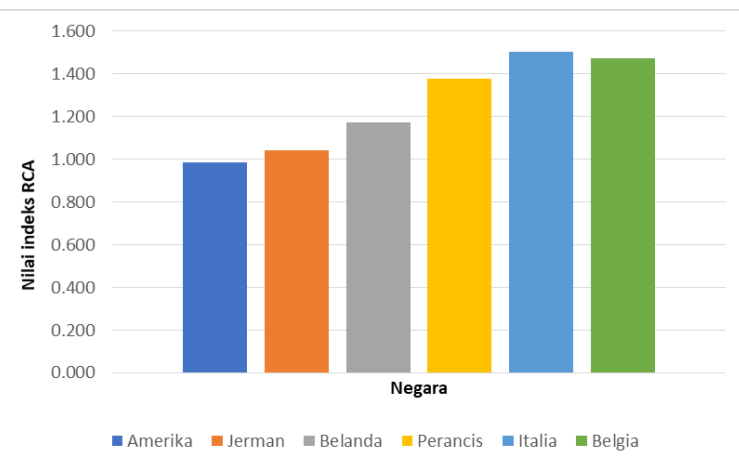

Gambar 10. Rata-Rata Indeks RCA ke Negara Tujuan Ekspor Tahun 2004-2018

Sementara itu, lada utuh Indonesia di pasar Amerika terlihat tidak berdaya saing karena memiliki rata-rata nilai RCA yang kurang dari satu, yaitu sebesar 0,98. Hal ini disebabkan oleh penurunan persentase ekspor lada utuh Indonesia ke Amerika pada tahun 2014 hingga 2018. Kondisi ini dikarenakan Amerika lebih banyak mengimpor lada utuh dari negara pesaing yaitu Vietnam (ITC 2019). Pada periode tahun 2004 hingga 2012 Indonesia menjadi negara pengekspor lada utuh terbesar ke Amerika, di mana nilai ekspor lada utuh Indonesia berada diatas nilai ekspor Vietnam, Brazil, dan India. Namun semenjak tahun 2014-2018 Vietnam menjadi negara pengekspor lada utuh terbesar ke negara Amerika menggantikan posisi Indonesia.

Berdasarkan penelitan yang dilakukan oleh Dalmari (2016), variabel pendapatan nasional dan harga lada Vietnam memiliki hubungan positif dan signifikan terhadap ekspor lada Indonesia ke Amerika Serikat, variabel nilai tukar/kurs dan harga lada Indonesia memiliki hubungan negatif dan signifikan terhadap ekspor lada Indonesia. 
Hal ini menunjukkan bahwa apabila harga lada Vietnam lebih tinggi dibandingkan harga lada Indonesia maka akan meningkatkan permintaan ekspor lada Indonesia ke Amerika dan hal ini berlaku sebaliknya. Oleh karena itu, hal tersebut menjadi tantangan sekaligus peluang bagi Indonesia untuk meningkatkan produktivitas ladanya, mulai dari sektor hulu hingga ke sektor hilir untuk menjaga kontinuitas ekspor lada di negara tujuan ekspor sehingga mampu dalam menghadapi persaingan dengan negara-negara pengekspor lada.

\section{Daya Saing Kompetitif}

Export Product Dynamics (EPD) merupakan suatu cara untuk mengidentifikasi keunggulan kompetitif dari komoditi atau produk ekspor sehingga dapat menentukan apakah di negara tujuan ekspor komoditi atau produk tersebut memiliki keunggulan kompetitif atau tidak. Nilai EPD ini dapat melihat daya saing kompetitif dari sisi posisi pasar Indonesia relatif dengan negara eksportir lainnya di negara importir. Berdasarkan perhitungan, posisi pasar lada utuh dapat dilihat pada Tabel 2 .

Tabel 2. Nilai EPD Lada Utuh Indonesia ke Negara Tujuan Ekspor Tahun 20042018

\begin{tabular}{clrrl}
\hline No & $\begin{array}{c}\text { Negara } \\
\text { Tujuan }\end{array}$ & $\begin{array}{c}\text { Sumbu } \\
\mathbf{X}\end{array}$ & $\begin{array}{c}\text { Sumbu } \\
\mathbf{Y}\end{array}$ & \multicolumn{1}{c}{ Posisi } \\
\hline 1 & Amerika & $-2,503$ & 0,005 & Lost Opportunity \\
2 & Belanda & 3,998 & $-0,096$ & Retreat \\
3 & Jerman & $-2,711$ & $-0,011$ & Retreat \\
4 & Italia & 0,062 & 0,024 & Rising Star \\
5 & Prancis & 0,302 & $-0,014$ & Falling Star \\
6 & Belgia & $-0,306$ & $-0,029$ & Retreat \\
\hline
\end{tabular}

Berdasarkan Tabel 2, pada tahun 20042018 posisi pangsa pasar lada utuh Indonesia di pasar Belanda, Jerman, dan Belgia berada pada posisi Retreat, di mana terjadinya penurunan pangsa ekspor lada utuh Indonesia ke negaranegara tersebut. Hal ini mengindikasikan lada utuh Indonesia tidak lagi memiliki keunggulan kompetitif karena lada utuh Indonesia tidak mampu bersaing dengan eksportir lain sehingga lada utuh Indonesia tidak diinginkan lagi di tiga negara tersebut. Hal ini dibuktikan dengan menurunnya nilai ekspor lada utuh Indonesia ke Jerman, Belanda, dan Belgia. Pada tahun 2017 nilai ekspor lada utuh Indonesia ke Jerman, Belanda, dan Belgia masing-masing bernilai US\$ 14.856, US\$ 9.509, dan US\$ 204. Sedangkan pada tahun 2018 nilai ekspor lada utuh ke Jerman turun hingga mencapai US\$ 5.685, ekspor ke Belanda turun sebesar US\$ 3.538, dan ekspor ke Belgia turun sebesar US\$38. Sebagian besar ekspor lada ke beberapa negara Uni Eropa di pasok oleh Brazil.

Posisi produk lada utuh Indonesia di negara Prancis berada pada posisi daya saing Falling Star. Di negara Prancis, pangsa pasar lada utuh Indonesia mengalami pertumbuhan negatif padahal pangsa pasar ekspornya mengalami pertumbuhan positif. Keadaan ini adalah merupakan keadaan yang tidak diinginkan oleh Indonesia sebagai pengekspor lada utuh karena lada utuh Indonesia kalah bersaing dengan eksportir lain. Lada adalah salah satu jenis rempah yang sering digunakan di Prancis untuk kebutuhan memasak atau saat menghidangkan makanan. Walaupun Prancis bukan negara produsen lada, namun di dunia, Prancis merupakan salah satu konsumen terbesar lada. Pada tahun 2018 total nilai impor lada utuh Prancis mencapai US\$ 39.633. oleh karena itu, bagi lada Indonesia, Prancis merupakan pasar yang sangat potensial.

Produk lada utuh Indonesia di negara Italia berada pada posisi daya saing Rising Star. Di negara ini, pertumbuhan pangsa ekspor dan pertumbuhan pangsa pasar lada utuh bernilai positif. Hal ini mengindikasikan bahwa permintaan lada utuh di negara Italia mengalami peningkatan dan pangsa pasarnya mengalami pertumbuhan pesat sehingga lada utuh Indonesia dikatakan memiliki keunggulan kompetitif. Posisi daya saing ini adalah posisi yang tertinggi atau yang paling ideal. Italia merupakan salah satu negara Uni Eropa dengan tingkat impor lada terbesar setelah Jerman, Belanda, dan Prancis. Hingga tahun 2018 nilai impor lada utuh Italia mencapai US\$18.376. Peningkatan impor lada di negara Uni Eropa ini seiring dengan perubahan gaya hidup, di mana masyarakat cenderung memilih produk alami yang aman, sehat, dan tidak menggangu lingkungan (Kemendag 2015). Hal ini merupakan sinyal positif bagi Indonesia untuk terus meningkatkan kualitas dan kuantitas ekspornya ke Italia. 
Menurut Kementerian Perdagangan (2015) terdapat beberapa hambatan untuk ekspor ke Uni Eropa, diantaranya hambatan tarif dan non tarif. Hambatan tarif mengenai pajak impor, di Jerman pajak impor untuk komoditi lada bisa mencapai 9,60\% ditambah lagi dengan Pajak Pertambahan Nilai (PPN), selain itu harga lada Indonesia juga berpengaruh pada ekspor, di mana harga lada yang ditawarkan Brazil dan negara eksportir lainnya jauh lebih rendah dibandingkan harga lada Indonesia, sehingga lada asal Indonesia kurang kompetitif dibandingkan dengan negara pesaingnya. Hambatan non tarif meliputi reputasi pesaing yang jumlah ekspornya terus meningkat setiap tahunnya, daya beli konsumen yang menginginkan komoditi berkualitas dengan harga murah, dan standar pengujian kehigienisan. Selain beberapa hambatan untuk ekspor ke Uni Eropa, Indonesia juga memiliki banyak peluang dan bisa memanfaatkan berbagai strategi untuk menembus pasar ekspor ke Uni Eropa. Peluang-peluang yang bisa dimanfaatkan Indonesia diantaranya adalah luasnya pasar yang mengakibatkan tingginya permintaan, perubahan pola hidup menjadi lebih sehat, dan kebutuhan pengembangan dan riset. Selain itu di beberapa negara Uni Eropa tarif impor yang dikenakan untuk Indonesia jauh lebih rendah dibandingkan dengan negara Brazil yang merupakan eksportir utama lada ke Uni Eropa (Kemendag 2015).

Posisi lada utuh Indonesia di pasar Amerika ada di posisi Lost Opportunity (terjadi penurunan pangsa pasar lada utuh, sehingga mengakibatkan kehilangannya kesempatan Indonesia untuk menjangkau pasar, namun lada utuh di negara ini masih manjadi produk yang kompetitif). Posisi daya saing Lost Opportunity memiliki arti bahwa Indonesia harus memperluas dan meningkatkan pangsa pasar ekspor lada utuh di pasar Amerika. Hal ini sejalan dengan posisi ekspor lada Indonesia yang digantikan oleh Vietnam, di mana pada periode tahun 2004-2012 Indonesia adalah eksportir utama lada ke Amerika dengan nilai ekspor mencapai US\$180.608, sedangkan pada tahun yang sama Vietnam hanya mengekspor US\$ 69.991.

Pada tahun 2013 Vietnam mulai meningkatkan nilai ekspornya ke Amerika. Hingga pada tahun 2014 Vietnam mampu mengekspor lada utuh ke Amerika sebesar US\$236.122, sedangkan Indonesia hanya mengekspor US\$ 90.794. Vietnam menaikkan nilai ekspornya sebesar US\$ 98.96 pada tahun 2014 dan nilai ekspor Indonesia pada tahun 2014 menurun hingga US\$ 58.183. Sejak tahun 2014, Vietnam telah menggantikan posisi Indonesia sebagai eksportir utama lada utuh ke Amerika, hal ini yang mendasari Indonesia berada pada posisi Lost Opportunity yang berdampak pada hilangnya kesempatan Indonesia untuk menjangkau pasar lada utuh Amerika. Tahun 2018 Indonesia hanya mengekspor US\$ 24.403 lada utuh ke Amerika, sedangkan Vietnam mampu mengekspor lada utuh ke Amerika hingga US\$ 133.104 .

\section{POSISI DAYA SAING}

Salah satu aspek penentu daya saing lada Indonesia adalah aspek permintaanya baik di pasar domestik maupun di pasar dunia. Perdagangan lada Indonesia selama ini, lebih berorientasi ekspor daripada untuk konsumsi domestik. Secara implisit ISP menjadikan sisi permintaan dan penawaran sebagai pertimbangan yaitu dengan mengidentikkan ekspor dengan suplai dalam negeri dan di sisi lain impor sebagai permintaan dalam negeri. Hal ini sesuai dengan teori perdagangan internasional, khususnya teori net of surplus, di mana produk atau komoditi di dalam negeri akan diekspor di pasar dalam negeri terjadi kelebihan atau surplus (Kemendag 2019). Mengacu pada perhitungan nilai ISP, Indonesia dapat dikatakan sebagai negara eksportir lada di pasar Amerika dan Eropa. Hal ini ditunjukkan oleh nilai rata-rata ISP yang tinggi. Nilai ISP ini lebih tinggi jika dibandingkan dengan nilai ISP negara pesaing utamanya yaitu Vietnam.

Hasil perhitungan menunjukkan nilai ratarata ISP Indonesia yaitu 0,95 per tahunnya. Nilai ini masih lebih tinggi jika dibandingkan dengan Vietnam, di mana nilai ISP negara ini adalah 0,84 per tahun (Tabel 3). Kondisi ini memperlihatkan bahwa lada merupakan komoditi yang memiliki daya saing kuat dan Indonesia cenderung sebagai negara pengekspor lada utuh (diindikasikan dengan penawaran dalam negeri lebih besar dari permintaanya). Indonesia dan Vietnam samasama berada pada tahap kedewasaan dengan nilai ISP berkisar antara 0,81 - 1,00. Jika dilihat 
berdasarkan tahun tertentu, Indonesia pernah mencapai nilai ISP tertinggi di tahun 2007. Hal ini karena nilai ekspor ladanya yang tinggi diikuti dengan nilai impornya yang rendah (sebagian besar produksi lada domestik untuk diekspor). Fenomena ini juga dialami negara Vietnam, di mana pernah mengalami nilai ISP tertinggi pada tahun 2005. Pada saat itu nilai ekspor ladanya yang tinggi disertai dengan nilai impor lada yang rendah. Namun ada perbedaan antar kedua negara ini, yaitu rendahnya nilai rata-rata ISP Vietnam karena selain nilai ekspor yang tinggi negara ini juga melakukan impor dengan nilai yang lebih besar dari nilai impor Indonesia.

Negara eksportir utama lada utuh Vietnam adalah Indonesia, menurut data ITC (2019) pada tahun 2018 Vietnam mengimpor lada utuh dari Indonesia hingga US\$20.679, impor tertinggi terjadi pada tahun 2015 mencapai US\$ 147.237, nilai impor tersebut naik hingga US\$ 111.708 dari tahun 2014. Selain dari Indonesia Vietnam juga mengimpor lada utuh dari Brazil, India, dan Malaysia. Sedangkan negara tujuan ekspor utama lada utuh Vietnam adalah Amerika, nilai ekspor tertinggi lada utuh Vietnam ke Amerika terjadi pada tahun 2016 dengan nilai ekspor mencapai US\$ 272.460 atau naik US\$ 52.465 dari tahun 2015. Perbandingn nilai ISP Indonesia dan Vietnam dapat dilihat pada Tabel 3.

Tabel 3. Nilai ISP Lada Utuh Indonesia dan Vietnam Tahun 2004-2018

\begin{tabular}{ccc}
\hline \multirow{2}{*}{ Tahun } & \multicolumn{2}{c}{$\begin{array}{c}\text { Indeks Spesialisasi } \\
\text { Perdagangan (ISP) }\end{array}$} \\
\cline { 2 - 3 } 2004 & 0,99 & Vietnam \\
2005 & 0,98 & 0,97 \\
2006 & 0,97 & 0,99 \\
2007 & 0,99 & 0,95 \\
2008 & 0,99 & 0,91 \\
2009 & 0,98 & 0,82 \\
2010 & 0,98 & 0,86 \\
2011 & 0,91 & 0,68 \\
2012 & 0,95 & 0,83 \\
2013 & 0,97 & 0,72 \\
2014 & 0,72 & 0,77 \\
2015 & 0,95 & 0,87 \\
2016 & 0,89 & 0,68 \\
2017 & 0,96 & 0,83 \\
2018 & 0,95 & 0,87 \\
\hline Rata-rata per tahun & 0,95 & 0,85 \\
\hline Sum & 0,84 \\
\hline
\end{tabular}

Sumber : ITC (data diolah) 2019

\section{SIMPULAN DAN SARAN}

\section{SIMPULAN}

Penelitian yang sudah dilakukan ini menghasilkan beberapa kesimpulan sebagai berikut:

1. Selama periode 2004-2018 telah terjadi penurunan terhadap luas lahan dan jumlah produksi lada Indonesia. Provinsi yang menjadi sentra produksi dengan luas lahan terbesar di Indonesia adalah Lampung, Kepulauan Bangka Belitung, Sulawesi Tenggara, Sulawesi selatan, dan Kalimantan Timur. Sedangkan terkait perkembangan ekspor, lada Indonesia mengalami perkembangan ekspor yang cukup berfluktuatif. Data periode 2004-2018 memperlihatkan jika negara ini menempati urutan kedua sebagai negara eksportir lada utuh terbesar di dunia, dengan rata-rata nilai ekspor mencapai US\$232.266

2. Indonesia memiliki daya saing ekspor lada di pasar Amerika dan Eropa. Hal ini berdasarkan pada indikator daya saing yang digunakan yaitu nilai RCA, EPD, dan ISP yang secara lebih rinci dapat dijelaskan berikut ini:

a. Pada indikator RCA, negara Indonesia dikatakan memiliki daya saing atau keunggulan komparatif di negara Jerman, Belanda, Prancis, Italia, dan Belgia yang ditunjukkan dengan nilai Indeks RCA ratarata lebih dari satu. Sementara itu, lada utuh Indonesia di pasar Amerika tidak berdaya saing karena memiliki rata-rata nilai RCA kurang dari satu. Hal ini terjadi karena ekspor lada utuh Indonesia ke Amerika periode 2014-2018 mengalami penurunan,

b. Mengacu pada Nilai EPD, posisi daya saing Indonesia untuk di negara Belanda, Jerman, dan Belgia berada pada posisi Retreat. Sedangkan posisi daya saing Indonesia di Italia berada pada posisi Rising Star, Prancis berada pada posisi Falling Star dan Amerika berada pada posisi Lost Opportunity.

c. Berdasarkan indikator ISP, Indonesia memiliki nilai rata-rata yang mencapai 0,95 per tahunnya. Nilai ini menunjukkan lada Indonesa masih memiliki daya saing yang kuat. Hal ini menunjukkan Indonesia sebagai negara pengekspor dari komoditi 
lada utuh (diindikasikan dengan suplai dalam negeri lebih besar dari permintaan dalam negeri).

\section{SARAN}

1. Untuk memenuhi permintaan pasar dan berdaya saing, Indonesia harus meningkatkan kualitas dan kuantitas produksi ladanya, Peningkatan kuantitas dapat dilakukan dengan perluasan lahan lada, Sedangkan peningkatan kualitas dapat dicapai dengan penggunaan benih unggul, perbaikan teknik budidaya, memaksimalkan penggunaan teknologi pada tahap pascapanen, dan standardisasi mutu lada,

2. Indonesia perlu menjaga kontinuitas ekspor ladanya di negara tujuan ekspor sehingga mampu bersaing dengan negara kompetitor lainnya.

3. Pasar tujuan yang dipilih sebaiknya adalah negara dengan kriteria pertumbuhan impor yang tinggi dan memiliki potensi untuk berkembang.

\section{DAFTAR PUSTAKA}

2013, Laporan Market Brief Peluang Usaha Lada/Merica di Italia [Internet], [diunduh pada 13 September 2019], Tersedia pada: http://djpen,kemendag,go,id/app frontend/ admin/docs/researchcorner/32813762990 $\underline{26, p d f}$

Athiyah FN, 2018, Analisis Daya Saing Lada Indonesia di pasar Asia [skripsi], Bogor (ID): Institut Pertanian Bogor,

Ariesha Y, 2017, Analisis Komparasi Daya Saing Ekspor Lada Indonesia Terhadap Vietnam Dan Malaysia Di Pasar ASEAN [skripsi], Jambi (ID): Universitas Jambi,

Basri F, Munandar H, 2010, Dasar-Dasar Ekonomi Internasional: Pengenalan Dan Aplikasi Metode Kuantitatif, Jakarta (ID): Kencana Prenada Media Group,

[BPS] Badan Pusat Statistik, 2019, Ekspor Lada Putih Menurut Negara tujuan Utama, tahun 2017, Jakarta (ID): BPS,
[BPS] Badan Pusat Statistik, 2019, Nilai Ekspor Indonesia, Jakarta (ID): BPS,

[BPS] Badan Pusat Statistik, 2019, Produk Domestik Bruto (PDB) Indonesia atas dasar harga konstan 2010 menurut sektor pertanian 2014-2018, Jakarta (ID): BPS,

[BPS] Badan Pusat Statistik, 2019, Negara tujuan ekspor lada Indonesia, Jakarta (ID): BPS,

Dalmari D, 2016, Faktor-Faktor yang Mempengaruhi Ekspor Lada Indonesia ke Amerika Serikat [skripsi], Bandung (ID): Universitas Pasundan,

Nabi, I, Luthria, M, 2002, Building Competitive Firms: Incentives and Capabilities. Directions in Development [Buku] World BankWashington, DC Diakses 10 November 2019 dari

https://openknowledge.worldbank.org/han dle/10986/15220

Hadianto J, Suminto, 2017, Daya saing produk pala Indonesia di pasar uni Eropa, Prosiding PPI Standardisasi, 2017 Okt 25; Makassar, Indonesia, Makassar (ID): Pusat Penelitian Dan Pengembangan Standardisasi, Badan Standardisasi Nasional,

[ITC] International Trade Center, 2019, Volume Ekspor Lada Dunia, [Internet], [diunduh pada 13 September 2019], Tersedia pada: https://www,trademap,org/tradestat,

[Kemendag], Kementerian Perdagangan, 2019, Indeks Spesialisasi Perdagangan, [internet], [diacu 12 November 2019]

[Kementerian Perdagangan], Kementerian Perdagangan Indonesia, 2015, Laporan Market Brief Produk Komoditi Lada (HS 0904) di Jerman [Internet], Tersedia pada: http://djpen,kemendag,go,id/membership/ data/files/6c52d-lada,pdf

Khairunisa GR, Novianti T, 2017, Daya Saing Minyak Sawit Dan Dampak Renewable Energy Directive (RED) Uni Eropa Terhadap Ekspor Indonesia Di Pasar Uni Eropa, Jurnal Agribisnis Indonesia, 5(2): 125-136,

Kiranta F, Meydianawathi LG, 2014, Analisis Tingkat Daya Saing Ekspor Biji Kakao Indonesia Tahun 2007-2012, E-Jurnal 
Ekonomi Pembangunan Universitas Udayana, 3(11): 502-512

Mahdi, NN, Suprehatin, S, 2021, Posisi Pasar Lada Indonesia di Pasar Global, Jurnal Ekonomi Pertanian dan Agribisnis, 5(2): 595-605

Marlinda, B, 2008, Analisis Daya Saing Lada di Pasar Internasional [skripsi], Bogor (ID): Institut Pertanian Bogor,

Nurdjannah N, 2006, Perbaikan Mutu Lada Dalam Rangka Meningkatkan Daya Saing Di Pasar Dunia, Perspektif, 2006 Jun 1; Bogor, Indonesia, Bogor (ID): Balai Besar Penelitian Dan Pengembangan Pasca Panen Pertanian,

Oktaviani, R dan Novianti T, 2014, Teori Perdagangan Internasional: Aplikasinya Di Indonesia, Bogor (ID): IPB Press, Institut Pertanian Bogor,

Kementrian Pertanian, 2018, Kiat Berkebun Lada, Jakarta (ID), Pusat Perpustakaan Dan Penyebaran Teknologi Pertanian,

Permatasari N, 2015, Analisis Daya Saing dan Faktor-Faktor yang Memengaruhi Ekspor Lada Indonesia ke Negara Tujuan Ekspor [skripsi], Bogor (ID): Institut Pertanian Bogor,

[Pusdatin], Pusat Data dan Sistem Informasi Pertanian, 2015, Outlook Lada [Internet], Tersedia pada: http://epublikasi,setjen,pertanian,go,id/arsi p-outlook/75-outlook-perkebunan/339outlook-lada-2015

Porter M, 1990, The Competitive Advantage Of Nation, Harvard Business Review, USA

Salvatore, 1997, Ekonomi Internasional, Edisi Kelima, Jakarta (ID): Erlangga.

Sari En, 2017, Analisis Dayasaing Kakao Dan Faktor-Faktor yang Memengaruhi Permintaan Ekspor Kakao Indonesia Di Negara Tujuan Ekspor Utama, [Skripsi], Bogor (ID): Institut Pertanian Bogor,

Susilowati SH, 2003, Dinamika Daya Saing Lada Indonesia, Jurnal Agro Ekonomi, 21(2): 122144

Tambunan T, 2004, Globalisasi dan Perdagangan Internasional, Bogor (ID): Ghalia Indonesia,
Yasri B, 2016, Analisis Kinerja Ekspor Non Migas Indonesia Ke Uni Eropa, Jurnal ilmiah EDUKASI, 4(3): 259-280 